\title{
Making decisions after floods: a consistency check of drivers across multiple flood types
}

\begin{abstract}
Bourgeoning flood hazards inflict significant negative effects on the welfare of households, particularly in developing countries. Rapid growth in scholarship on impacts and flood coping strategies from developing countries is therefore a justified consequence. However, identifying the determinants of coping decisions across space and time has so far attracted little attention, in spite of their policy implications. Current efforts have been largely limited to Isolated, individual case study floods of little relevance for broad-based policy prescription. This study examines the drivers for coping decisions, using predominantly quantitative data from 106 direct flash and riverine flood victims from six flood-affected communities in Cameroon. The capital portfolios of the Sustainable Livelihoods Framework were appropriated to categorize and identify key drivers for coping decisions. Descriptive analysis reveals that almost 70 percent of all flood victims predominantly adopted community-embedded, informal coping strategies, much in line with contemporary trends in the literature. Logistic regression analyses revealed that access to social, human, natural and physical capitals were consistent drivers of coping decisions, irrespective of flood type. Significant relationships were however observed only for flash floods $(\mathrm{p}=0.05)$. The results are strongly relevant, as the tested variables explained over 75 percent of the variance in the entire sample. The findings lead us to contend that policy is better informed by analyzing consistencies in drivers for flood coping decisions across space and time, especially if multiple case studies are modeled using similar methodologies. Further research is however necessary to ground this contention.
\end{abstract}

Keywords: Determinants, coping, flash and riverine floods, decision-making, multiple cases
Volume 3 Issue 6 - 2018

\author{
Salliana Ateh Fondo,' Roland Azibo Balgah, ${ }^{2}$ \\ Theobald Mue $\mathrm{Nji}^{3}$ \\ 'Junior Research Fellow, School of Life Sciences, Technical \\ University of Munich, Germany \\ ${ }^{2}$ Senior Lecturer and Senior Research Fellow, College of \\ Technology, The University of Bamenda, Republic of Cameroon \\ ${ }^{3}$ Research Associate, Faculty of Social and Management Sciences, \\ University of Buea, Cameroon
}

\begin{abstract}
Correspondence: Roland Azibo Balgah, Senior Lecturer and Senior Research Fellow, College of Technology, The University of Bamenda, P.O. Box 39 Bambili, Northwest Region, Republic of Cameroon, Tel (+237) 6705II067,

Email balgahraland@gmail.com
\end{abstract}

Received: September 25, 2018 | Published: December 17, 2018

\section{Introduction}

The unprecedented upsurge in climate-related extreme events around the world has become an almost permanent but unfortunate reality. Burgeoning hydro-meteorological hazards, particularly floods inflict direct and indirect negative economic, psychosocial, physical, human and environmental impacts on their victims. According to the World Bank, ${ }^{1}$ hydro-meteorological disasters alone accounted for $87 \%(18,200)$ of all disasters, $74 \%$ of total recorded economic losses (US\$2.6 trillion), and $61 \%$ of total lives lost (1.4 million) between 1980 and 2012. Statistics from CRED ${ }^{2}$ suggest that floods accounted for about $50 \%$ of all global weather-related hazards between 1995 and 2014, representing an increase of 40 additional floods per annum over the same period. The negative and sometimes largely irreversible impacts of floods on agriculture, water supply, natural and physical resources, ecosystems and related services, and spread of diseases have been systematically and widely recorded..$^{3-6}$

The general consensus emerging in the topical literature is that flood effects are more severe in developing countries, even if hazard response strategies are becoming increasingly complex in both developed and developing countries. ${ }^{7-10}$ It is tempting to assume that an appropriate explanation for the differentiated capacity to prevent, mitigate or cope with flood hazards generally observed between developed and developing countries is inherent in the failure of state and marketrelated management instruments, which generally characterizes many developing countries. ${ }^{11,12}$ On the contrary, empirical evidence from flood-affected communities and victims across the developing world suggests that effectively functioning (essentially communitybased) preventive, mitigating coping strategies have been developed and/or appropriated under such circumstances. ${ }^{13-15}$ This assumption appears too simplistic, especially as flood research in developing countries is still very basic, and currently overwhelmed by isolated, sporadic individual case studies. Justification for case-specificity emanates from the premise that place-based studies are crucial in developing context-adapted solutions for flood hazard management practices which can effectively inform policy decisions, given that (1) no two floods are exactly the same; and (2) flood effects are influenced by factors specific to each context. ${ }^{16,17}$ More so, given the current emphasis on community resilience for effective, sustainable and long term flood management, ${ }^{18}$ the focus on context-specific case studies is a logical choice. However, the escalation of floods warrants policy prescriptions which are at best broad-based, thus imbibed with potentials for wider applications across space and time. This necessitates research which either systematically condenses existing isolated case studies, or empirically examines many case studies at once, in order to identify consistent patterns. A possible problem with the first approach is methodological inconsistencies that may abound individual case studies. This raises issues of reliability, leaving the latter as the best choice option. For this reason, we use identical approaches and similar instruments to empirically examine the drivers of coping decisions for victims of multiple flash and riverine floods. $\mathrm{Al}^{\mathrm{A}}$ in Cameroon.

${ }^{\mathrm{A}}$ Flash floods are short, sudden localized water overflow events emanating from great volumes of water as a result of excessive rainfall or snowmelt, usually within periods as short as six hours. Flash floods are often the outcomes of sudden increase in temperatures, rainfall and/or snow. Riverine (or fluvial) floods occur mostly on flood plains or wash lands when water flow exceed the capacity of the streams/rivers, spilling over natural banks or artificial embankments. Major causes of riverine floods are intense precipitation or snow/glacial melt $\left(\mathrm{WMO}^{26}\right)$. 


\section{Coping with flood hazards: analytical approaches and drivers}

Arguably, the asset portfolio of the Sustainable Livelihoods Framework (SLF) $)^{19,20}$ has lent itself as an appropriate approach to systematically conceptualize and measure the effects of flood hazards, given the many possible outcomes of hazards. ${ }^{\mathrm{A} 2}$ This probably explains the strongly demonstrated interest in appropriating the SLF in modeling floods and other natural hazards. ${ }^{21,22}$ In the short-term for instance, most flood victims often draw on available capital assets to minimize the immediate effects. ${ }^{23}$ Very often and depending on conditions preceding such events, flood victims often demonstrate differentiated preference for consumption, asset or income smoothing. ${ }^{24-27}$

In general, responses to flood hazards are classified as either formal or informal. ${ }^{23}$ Formal responses on the one hand consist of a plethora of state and market options which flood victims appropriate to prevent, mitigate or cope with precedented or unprecedented flood hazard effects. Popular examples include hazard-based insurance schemes and formal savings. On the other hand, informal responses describe the multitude of measures taken/adopted at individual, household or community levels to protect against risks or to fight against floods, in the presence or absence of public or market based arrangements. Some examples include buying, selling and saving of real assets, calculated marriages, and borrowing from informal social networks. ${ }^{21-23}$ What drives victims' preference for either formal or informal coping instruments? According to the dominant school of thought, preference for informal strategies are largely motivated by failing, dysfunctional or inexistent state and market-based (formal) instruments. . $9,23,27$ While this seems logical, it falls short of explaining why victims in developing countries often preferably adopt informal strategies, even in the presence of functioning formal flood hazard institutions. Factors such as flood experience, age and gender, asset portfolio (vulnerability) and individual perceptions have proven to be robust drivers in many isolated flood case studies. ${ }^{8,28,29}$ Other emerging drivers include education, previous exposure and household size. ${ }^{30-33}$ The list of drivers is inexhaustible, and is likely to increase with the number of case studies. However, comparisons across case studies sometimes reveal contrasting evidences. For instance, Poussin et al. ${ }^{34}$ and Shitangsu \& Joyant ${ }^{35}$ observed that household head's age affected coping choices in France and Bangladesh respectively. On the contrary, Grothmann \& Reusswig ${ }^{36}$ rather found out that the age of the household head had no influence on coping decisions of disaster victims. Similar contrasting results surround the roles of income, age, household size and education..$^{8,25,37}$

The divergence indicated above does not facilitate the task of broad-based flood policy formulation and implementation of particular relevance in developing countries where flood effects are highest. ${ }^{5}$ As previously mentioned, one reason for this might (arguably) be the different methodological approaches applied in the isolated case studies, which raises questions of reliability. We contribute to this discourse by applying similar methodological approaches to model multiple (flash and riverine) floods in Cameroon. These two flood types are the most dominant in the country.

\footnotetext{
${ }^{A 2}$ According to Chambers ${ }^{19}$ and Scoones, ${ }^{20}$ the major forms of assets engrained in the SLF include human, economic, financial, physical, social and natural capitals. Some of these capitals are tested in this article as to the extent to which they influence coping decisions of victims of flash and riverine floods in Cameroon.
}

\section{Materials and methods}

This paper examines the determinants for coping decisions among victims of flash and riverine floods in the South West Region of Cameroon. Three communities affected by flash floods and three others affected by riverine floods in the southwest region of Cameroon were purposively selected for the study, as both flood types are the most dominant forms in Cameroon. Only communities affected by the two types of floods within the last 10 years were retained for the study, given that data was to be obtained largely through recall.

76 direct victims of flash flood in the three selected communities and 30 from three riverine flood communities were randomly selected and interviewed using a structured questionnaire. The sampling unit in the study was the flood victim and a structured questionnaire modified following Balgah et al. ${ }^{15}$ was applied to model drivers for coping decisions for the flood hazard victims. The asset portfolios of the Sustainable Livelihoods Framework were strongly represented in the questionnaire..$^{25,38}$

Data were collected by trained enumerators and experienced researchers from $14^{\text {th }}$ to $22^{\text {nd }}$ December 2016 . The questionnaire was pretested and modified accordingly before being used for data collection. Interviews were solely conducted by trained enumerators and researchers, irrespective of whether the victim could read and write. Interview and data recording was done at the victims' homestead. This allowed the research team to observe any remnants of flood impacts, or any ongoing/visible coping activities. The quantitative data collection exercise was therefore complemented with direct field observations. Collected data was analyzed using SPSS (Statistical Package for Social Sciences), version 20.0. Descriptive statistics were performed to identify similarities and differences between victims of flash and riverine floods retained for the study. Additionally, logistic regressions were carried out to ascertain the key drivers of victims' decisions to adopt specific coping strategies by flood category.

The binary regression model can be conceptualized as follows:

$$
D=\alpha+\beta_{1} I_{1}+\beta_{2} I_{2} . .+. .+\beta_{n} I_{n}+e(1)
$$

Where, D is a binary variable $(1,0)$, indicating the flood victims' coping decision,

$\alpha$ is the constant,

$\beta$ is the predictors,

$I_{1}-I_{n}$ are independent variables influencing flood victims' adoption decisions, and $e$ is the error term.

Results were analyzed generally adopting a 90\% confidence interval $(\alpha=0.1)$. The empirical results are presented and discussed in the next section.

\section{Results and discussion}

\section{Descriptive statistics}

\section{Socioeconomic characteristics by flood type}

In this section, we describe the sample, essentially comparing flash and riverine flood victims. A comparative analysis of flash and riverine flood victims indicates a slightly higher number of female than male victims across both flood types ( $\sim 54 \%$ for flash floods and $51 \%$ for riverine floods respectively). A significant number of all victims depended on the non-farm sector for their livelihoods (slightly 
above $76 \%$ and $88 \%$ respectively: $\mathrm{X}^{2}=4.949, \mathrm{p}=0.02$ ). The results are presented in Figures 1A.

The majority of all respondents had attained secondary school level of education (slightly above $42 \%$ for flash and $46 \%$ for riverine flood victims), seconded by those who had only primary level of education $\left(\mathrm{X}^{2}=14.888, \mathrm{p}=0.02\right)$, as displayed in Figure 2 .

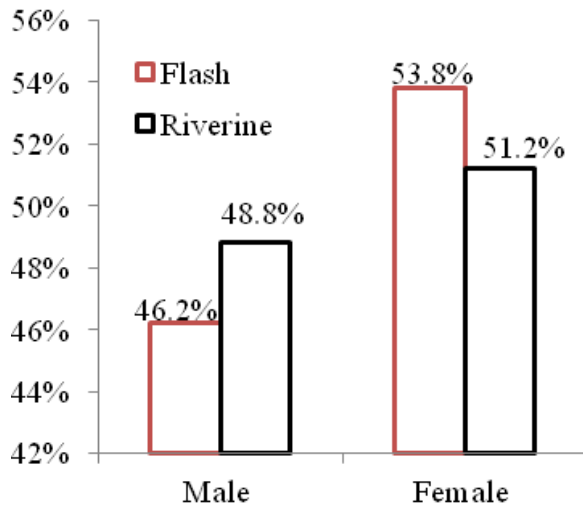

Sex distribution of sample
Most of the respondents (over 65\%) are married and are still living with their spouses, even if this was higher for flash flood victims $(70 \%$ and $63 \%$ respectively). Given that marriage often extends individual networks, ${ }^{15}$ we expect this to play an important role in driving victims' decisions to prefer informal coping strategies after flood hazards (Figure 3).

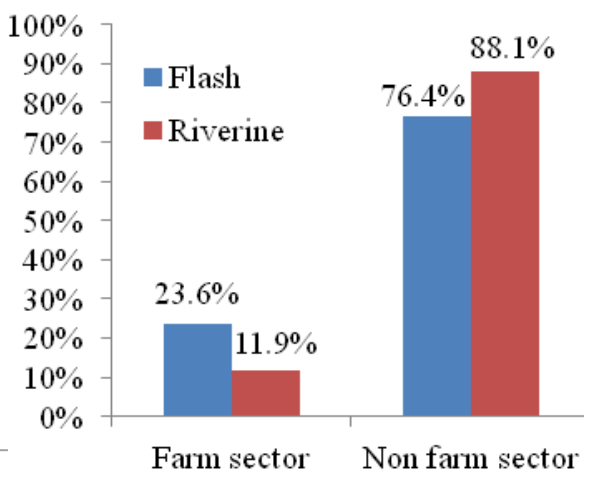

Main occupation of respondents

Figure I(A): Sex distribution; (B): Main occupation of sample population.

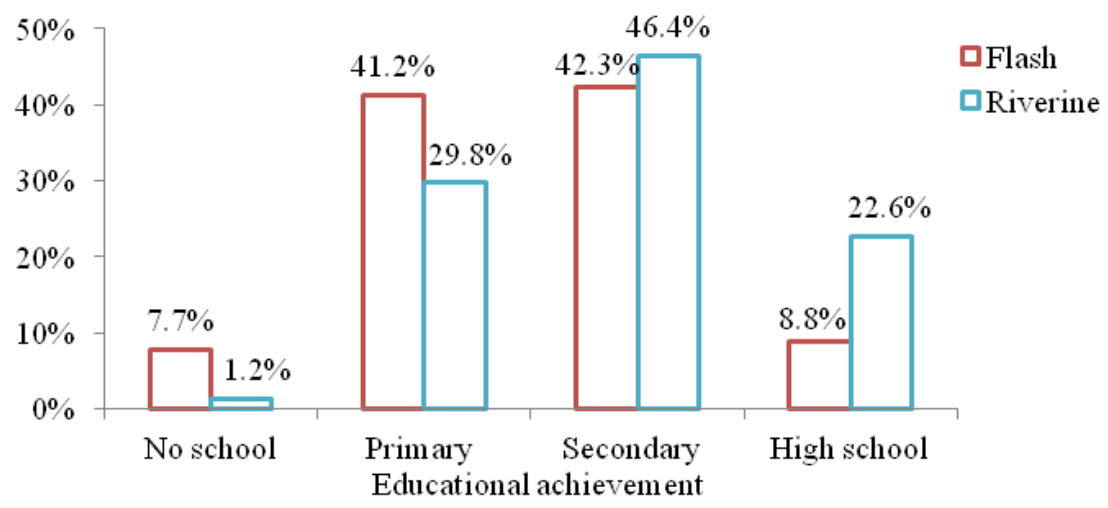

Figure 2 Educational attainment.

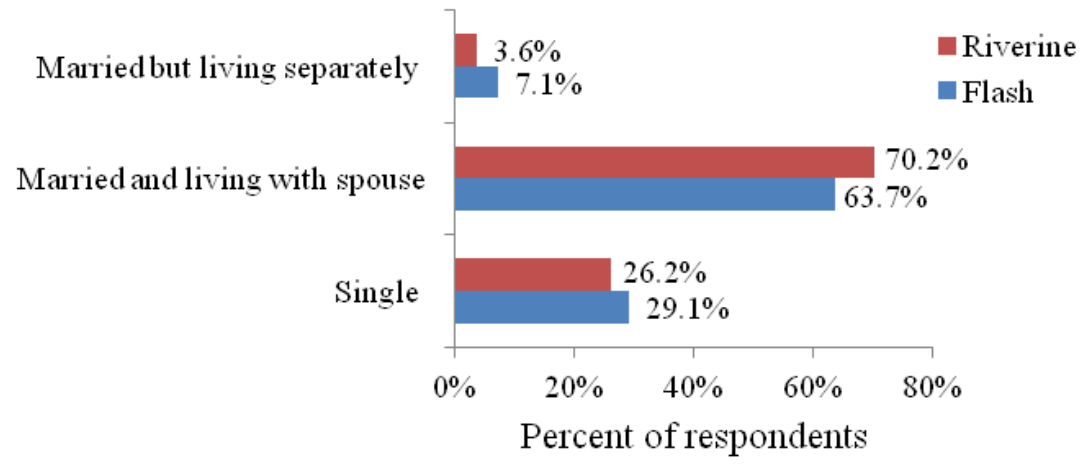

Figure 3 Civil status of respondents.

Notes:
a. Figures have been rounded to the nearest 10 FCFA
b. 1 US\$ $=$ FCFA552.799 (BEAC exchange rate, 2018)
c. $\mathrm{FCFA}=$ Franc de la Communauté Financière d'Afrique

The additional results from Table 1 reveal that while the mean age of the sample population was slightly above 45 years, the average household size is 6 persons with an estimated monthly income of FCFA 89,300 ( $\approx$ US\$ 162). More so, the flood victims have stayed on average for about 17 years in their respective communities. This suggests that flood experience should be a key determinant for coping 
decisions. The oldest person was 86 years while the youngest was 21. A wide variation was observed in the household size, which ranged from 1 to 21 . At the $95 \%$ level of confidence $(\alpha=0.05)$, the results from Table 1 showed significant differences between the household size and longevity of stay in the flash flood and the riverine communities ( 6 and $7, p=0.01$, slightly above 17.5 years and 15 years, $\mathrm{p}=0.01$ respectively). A similar disparity was observed at the level of the household incomes, some households earned up to FCFA 500,000 $(\approx$ US\$ 905) while others earned only FCFA5000 ( $\approx$ US\$ 9) a month. Income disparity is likely to seriously affect coping strategies, even if this was statistically significant only at the $10 \%$ level. Though not significant at the $5 \%$ level, the difference in average monthly income,
FCFA $83,270(\approx$ US\$ 150) for the flash flood victims and FCFA $103,330(\approx$ US $\$ 187)$ for the riverine ones, a difference of FCFA20, 060 ( $\approx$ US\$ 36) cannot be neglected. No significant difference was observed for the ages of flash and riverine flood victims.

\section{Type of disaster management option preferably adopted by respondents}

Following Holzmann, ${ }^{23}$ Heitzmann et al. ${ }^{39}$ and Anthony et al. ${ }^{40}$, we classified the disaster management types in to ex-ante and ex-post strategies as well as into informal and formal responses. The dominant categories in the sample are presented in Table 2.

Table I Comparative analysis of additional demographic variables by flood type

\begin{tabular}{|c|c|c|c|c|c|c|}
\hline Variable & Sample mean & Flood type & Mean & Std. Deviation & Std. Error Mean & p-value \\
\hline \multirow{2}{*}{ Age of respondent } & \multirow{2}{*}{45.47} & Flash flood & 45.12 & 12.343 & 1.066 & \multirow{2}{*}{0.55} \\
\hline & & Riverine flood & 46.22 & 11.623 & 1.453 & \\
\hline \multirow{2}{*}{ Household size } & \multirow{2}{*}{5.95} & Flash flood & 5.6 & 3.071 & 0.231 & \multirow{2}{*}{0.01} \\
\hline & & Riverine flood & 6.74 & 2.793 & 0.318 & \\
\hline \multirow{2}{*}{ Estimated monthly income/FCFA } & \multirow{2}{*}{89,300} & Flash flood & 83,270 & 85,970 & 6,590 & \multirow{2}{*}{0.05} \\
\hline & & Riverine flood & 103,330 & 93,140 & 109,00 & \\
\hline \multirow{2}{*}{ Longevity in the community } & \multirow{2}{*}{16.74} & Flash flood & 17.53 & 15.131 & 1.128 & \multirow{2}{*}{0.01} \\
\hline & & Riverine flood & 15.02 & 11.993 & 1.316 & \\
\hline
\end{tabular}

Table 2 Management strategies by timing and flood type

\begin{tabular}{|c|c|c|c|c|}
\hline Flood management strategy/ type & Sample Total & Flood type & Percentage & p-value \\
\hline Ex-ante strategy & \multirow{2}{*}{$79.70 \%$} & Flash flood & $75.90 \%$ & \\
\hline \multirow[t]{2}{*}{ (prevention, mitigation) } & & Riverine flood & $24.10 \%$ & $\left(X^{2}=1.766\right)$ \\
\hline & \multirow{2}{*}{$20.30 \%$} & Flash flood & $66.50 \%$ & $\mathrm{P}=0.12$ \\
\hline Ex-post (coping) strategy & & Riverine flood & $33.50 \%$ & \\
\hline \multirow[t]{2}{*}{ Informal response } & \multirow{2}{*}{$67.70 \%$} & Flash flood & $87.50 \%$ & \\
\hline & & Riverine flood & $88.10 \%$ & $\left(X^{2}=0.019\right)$ \\
\hline \multirow[t]{2}{*}{ Formal response } & \multirow{2}{*}{$32.30 \%$} & Flash flood & $12.50 \%$ & $\mathrm{P}=0.53$ \\
\hline & & Riverine flood & $11.90 \%$ & \\
\hline
\end{tabular}

In general, it can be inferred from Table 2 that the study population adopted more of ex-ante/adaptive management strategies than expost/coping strategies (about $80 \%$ and 20\% respectively). This indicates the possible importance of flood experience in influencing coping decisions. A closer look at Table 2 indicates that ex-ante and ex-post flood management strategies are adopted more in the flash flood communities (over $75 \%$ and $66 \%$ respectively) than in the riverine communities (slightly above $24 \%$ and $33 \%$ respectively). As explained for instance by Cardona et al. ${ }^{41}$ this is probably due to the fact that ex-ante (adaptive) capacity positively impacts the ability of an individual, family, community, or other social group to adjust to unexpected changes in the environment, thereby guaranteeing survival and livelihood sustainability. The majority of the respondents from both flash and riverine flood communities (almost 88\%) adopted mainly informal management strategies to buffer the negative consequences of respective floods. These results resonate for instance with those of Balgah et al. ${ }^{15}$ who observed that households often appropriated mostly informal response mechanisms in coping with natural hazards in Cameroon.

\section{Drivers for coping decisions}

\section{Importance of drivers for coping decisions for the entire sample}

Binary logistic regression analyses were performed in order to identify key drivers for the choice of informal coping strategies across the different floods. The dependent variable (the type of response) took 1 for informal responses, and 0 for formal coping mechanisms. 24 explanatory variables were included in the analysis, categorized under the different asset portfolios of the Sustainable Livelihoods Framework. ${ }^{20,25}$ These included social capital variables (belonging to a group, number of groups, leadership in groups, gender, years in community, marital status and literacy level), human capital variables (age, educational, fear of future floods, level of household damage, household size, number of floods witnessed and main occupation), natural/fixed capital variables (rooms per capita, house ownership, land ownership, number of lands owned and the total land area), and financial capital variables (income and per capita income).

In the first step, we did a combined analysis for the entire sample (Tables 3-5). We observed that in general, the educational level, the 
flood type, household size, total area of land, marital status, belonging to a group, main occupation, literacy level, number of years living in the community, number of flood events witnessed (flood experience), level of damage to household and rooms per capita influenced the coping decisions of the flood victims. On the other hand, the age of the victim, total number of groups, number of land owned, leadership in groups, house ownership, religious affiliations, fear of future floods and number of formal groups did not significantly influence these decisions, irrespective of flood type. Based on these results, we then conducted a comparative analysis between the flash flood and riverine flood communities. These results are presented in Tables 3-9 following the different livelihood capitals of the Sustainable Livelihood Frameworks.

Table 3 Flood coping determinants for the entire sample

\begin{tabular}{|c|c|c|c|c|c|}
\hline Variable & B & S.E. & Wald & df & $\operatorname{Exp}(B)$ \\
\hline Age of respondent & $-.046^{*}$ & 0.031 & 2.21 & 1 & 0.955 \\
\hline Educational achievement & 0.542 & 0.58 & 0.874 & 1 & 1.72 \\
\hline Flood type & 0.053 & 0.617 & 0.007 & 1 & 1.055 \\
\hline Total number of groups & -0.463 & 0.411 & 1.266 & 1 & 0.629 \\
\hline Household size & 0.173 & 0.139 & 1.537 & 1 & 1.188 \\
\hline Total land area & 0.103 & 0.091 & 1.283 & 1 & 1.108 \\
\hline Number of plots owned & -0.764 & 0.64 & 1.423 & 1 & 0.466 \\
\hline Leadership in groups & -0.038 & 0.816 & 0.002 & 1 & 0.963 \\
\hline Marital status & 0.772 & 0.693 & 1.242 & 1 & 2.164 \\
\hline Membership in a group & $1.567^{*}$ & 0.924 & 2.874 & 1 & 4.793 \\
\hline Main occupation & 0.917 & 1.085 & 0.715 & 1 & 2.503 \\
\hline Owner of the house & -0.104 & 0.26 & 0.161 & 1 & 0.901 \\
\hline Land owned & -0.279 & 0.736 & 0.144 & 1 & 0.756 \\
\hline Literate & 0.983 & 1.197 & 0.675 & 1 & 2.673 \\
\hline Religious affiliation & -1.56 & 1.435 & 1.182 & 1 & 0.21 \\
\hline Longevity in the community & $.033 *$ & 0.024 & 1.847 & 1 & 1.034 \\
\hline Number of flood events witnessed & $.129 *$ & 0.073 & 3.071 & 1 & 1.137 \\
\hline Flood damage cost & 0 & 0 & 0.96 & 1 & 1 \\
\hline Number of formal groups & -0.42 & 0.833 & 0.255 & 1 & 0.657 \\
\hline Fear of future flood & -0.179 & 0.358 & 0.25 & 1 & 0.836 \\
\hline Level of household damage & 0.047 & 0.282 & 0.028 & 1 & 1.048 \\
\hline Rooms per capita & 0.073 & 0.214 & 0.116 & 1 & 1.076 \\
\hline Household income & 0 & 0 & 0.269 & 1 & 1 \\
\hline Per capita income & 0 & 0 & 0.019 & 1 & 1 \\
\hline Constant & -2.916 & 4.743 & 0.378 & 1 & 0.054 \\
\hline
\end{tabular}

Note: *, Significant at $10 \%$;**, Significant at $5 \%$; and $* * *$, Significant at $1 \%$

Table 4 Omnibus Tests of Model Coefficients for flash and riverine flood victims

\begin{tabular}{lllll}
\hline Flood type & Model form & Chi-square & df & Sig. \\
\hline \multirow{3}{*}{ Flash flood } & Step & 53.221 & 26 & 0.001 \\
& Block & 53.221 & 26 & 0.001 \\
& Model & 53.221 & 26 & 0.001 \\
Riverine flood & Step & 45.304 & 25 & 0.008 \\
& Block & 45.304 & 25 & 0.008 \\
& Model & 45.304 & 25 & 0.008 \\
\hline
\end{tabular}




\section{Comparative analysis of drivers for coping with flash and riverine floods}

Further logistic regression analysis indicated a significant relationship between the independent variables and the dependent variable (the type of response where, $1=$ informal coping strategy, and $0=$ formal coping strategy $\left(\mathrm{X}^{2}=53.221, \mathrm{p}=0.001\right)$. The model outputs suggest that selected variables significantly explain the coping decisions in our sample ( $\mathrm{p}=0.001$ ) (Table 4$)$, that is, over $70 \%$ of the coping decisions for flash flood victims, and $85 \%$ for riverine flood victims respectively (Table 5).

Table 5 Model Summary for flash and riverine flood victims

\begin{tabular}{llll}
\hline Flood type & $\begin{array}{l}\mathbf{- 2} \text { Log } \\
\text { likelihood }\end{array}$ & $\begin{array}{l}\text { Cox \& Snell } \\
\text { R Square }\end{array}$ & $\begin{array}{l}\text { Nagelkerke } \\
\text { R Square }\end{array}$ \\
\hline Flash flood & 31.089 & 0.338 & 0.705 \\
Riverine flood & 0 & 0.568 & 0.85 \\
\hline
\end{tabular}

Given these outputs, we then proceed with a comparative analysis based on the capital portfolios embedded in the Sustainable Livelihoods Framework. The idea is to identify if there are specific trends pertaining to the different capital portfolios, as to the extent to which they influence the coping decisions amongst flash and riverine flood victims.

\section{Social capital}

Using seven social capital variables, it was observed that belonging to a group or network, the total number of networks, and longevity in the flood communities strongly influenced victims' coping decisions in both flood types (based on the beta values), even if they were statistically significant only for flash flood victims $(p \leq 0.05)$. Similar trends were observed with the marital status and literacy level of household heads even if these were again only statistically significant for flash flood victims $(\mathrm{p} \leq 0.1)$. The gender of the victim had no influence over flood management decisions in all flood communities. Zaalberg et al. ${ }^{32}$ reported similar results among flood victims in the Netherlands. The results can be seen in Table 6 .

The accumulation of social capital through networking as well as marriage increases the number of friends and family members respectively that the flood victims can rely on in times of distress. Balgah et al. ${ }^{15,21}$ reported similar results for flood victims in northwest Cameroon, where networking was found to positively shape flood victims' decisions to adopt informal management strategies over formal ones.

\section{Human capital}

The regression outputs on human capital variables are presented in Table 7. The beta values suggest that flood perceptions, household size, flood experience and the main occupation of the victims were robust drivers affecting flood coping decisions. This is in line with previous findings (e.g. Zaalberg et al., ${ }^{32}$ Meceli et al., ${ }^{31}$ Siegrist ${ }^{42}$ and Terpstra $)^{43}$. For instance flood perceptions tend to affect coping strategies, given that people's emotions (e.g. from past experiences) influence their cognitive evaluation of future risks and their respective behavioral response. ${ }^{32,43}$

Interestingly, the age of the victim displayed a negative relationship with flood coping decisions across both flood types, contradicting for instance, Poussin et al. ${ }^{35}$ who all found age to positively influence flood coping strategies. This indicates that older people are less interested in engaging in coping strategies, probably because they are rational, given that they stand to benefit least. Contrasting trends were observed on educational attainment which was positive and negative among flash and riverine flood victims respectively. In line with the results from social capital variables, human capital variables were generally more statistically significant for flash than for riverine floods.

Table 6 Social capital variables

\begin{tabular}{lllll} 
Variable & Flood type & B & S.E & Exp(B) \\
Belong to a network & Flash & $10.425^{* *}$ & 4.477 & 33705.714 \\
& Riverine & 45.292 & 62065.207 & 4680 \\
Total number of & Flash & $-9.614^{* *}$ & 3.798 & 0 \\
groups/networks & Riverine & 48.871 & 14761.55 & 1676 \\
Leadership in & Flash & 5.434 & 4.577 & 228.985 \\
groups & Riverine & -195.632 & 50972.812 & 0 \\
Gender & Flash & -2.354 & 2.039 & 0.095 \\
\multirow{2}{*}{$\begin{array}{l}\text { Length of stay in } \\
\text { the community }\end{array}$} & Riverine & -40.58 & 19874.357 & 0 \\
& Flash & $.286^{* *}$ & 0.125 & 1.331 \\
Marital status & Riverine & -0.704 & 2211.819 & 0.494 \\
& Flash & $5.565^{*}$ & 2.886 & 261.133 \\
Literacy level & Riverine & 71.191 & 61021.374 & 8278 \\
& Flash & $-8.253^{*}$ & 4.154 & 0 \\
Constant & Riverine & 346.529 & 152.225 & 3.13 \\
& Flash & 80.155 & 34.81 & 6468 \\
\hline & Riverine & 400.534 & 1526.296 & 8.903
\end{tabular}

Note: *, Significant at 10\%; **, Significant at 5\%; and ***, Significant at $1 \%$

Table 7 Human capital variables

\begin{tabular}{|c|c|c|c|c|}
\hline Variable & Flood type & B & S.E & $\operatorname{Exp}(B)$ \\
\hline \multirow{2}{*}{ Age } & Flash & $-.259 * *$ & 0.13 & 0.772 \\
\hline & Riverine & -5.071 & 2433.692 & 0.006 \\
\hline \multirow{2}{*}{$\begin{array}{l}\text { Educational } \\
\text { achievement }\end{array}$} & Flash & $6.728 * *$ & 2.856 & 835.578 \\
\hline & Riverine & -106.262 & 173.119 & 0 \\
\hline \multirow{2}{*}{$\begin{array}{l}\text { Perceptions to } \\
\text { future floods }\end{array}$} & Flash & $2.557 *$ & 1.62 & 12.897 \\
\hline & Riverine & 3.612 & 8.467 & 37.046 \\
\hline \multirow{2}{*}{$\begin{array}{l}\text { Level of household } \\
\text { damage }\end{array}$} & Flash & $-1.659 *$ & 0.91 & 0.19 \\
\hline & Riverine & 2.555 & 2.991 & 12.872 \\
\hline \multirow{2}{*}{ Household size } & Flash & 1.028 & 0.89 & 2.795 \\
\hline & Riverine & 24.366 & 38.002 & 3820 \\
\hline \multirow{2}{*}{$\begin{array}{l}\text { Number of floods } \\
\text { witnessed }\end{array}$} & Flash & $.392 *$ & 0.207 & 1.481 \\
\hline & Riverine & 7.896 & 9.007 & 2686.902 \\
\hline \multirow{2}{*}{ Main occupation } & Flash & 1.397 & 1.905 & 4.044 \\
\hline & Riverine & 5.741 & 45.314 & 311.279 \\
\hline \multirow{2}{*}{ Constant } & Flash & 80.155 & 34.81 & 6468 \\
\hline & Riverine & 400.534 & 1526.296 & 8.903 \\
\hline
\end{tabular}

Note: *, Significant at $10 \%$; **, Significant at 5\%; and ***, Significant at I\% 


\section{Natural and physical capitals}

Table 8 presents the results of the analysis of natural and physical capitals on driving flood victims' coping decisions. The trends are generally similar to the previous capital portfolios. Statistically significant influences were observed on rooms per capita, house ownership and number of plots $(\mathrm{p} \leq 0.1)$. Similar results have been reported elsewhere (see for instance Poussin et al., ${ }^{35}$ and Mishra \& Suar $)^{44}$.

Table 8 Natural and physical capital variables

\begin{tabular}{lllll}
\hline Variable & Flood type & B & S.E & Exp(B) \\
\hline \multirow{2}{*}{ Rooms per capita } & Flash & $3.114 * *$ & 1.293 & 22.512 \\
& Riverine & 9.658 & 12.318 & 15653.103 \\
Land owned & Flash & 1.729 & 3.719 & 5.638 \\
& Riverine & -292.572 & 636.933 & 0 \\
House ownership & Flash & $1.812^{*}$ & 0.947 & 6.122 \\
& Riverine & -25.854 & 16.758 & 0 \\
Number of plots & Flash & $-1.659^{*}$ & 0.91 & 0.19 \\
owned & Riverine & 188.323 & 220.313 & 6.135 \\
Total land area & Flash & -2.657 & 2.433 & 0.07 \\
& Riverine & -89.249 & 116.867 & 0 \\
Constant & Flash & 80.155 & 34.81 & 6468 \\
& Riverine & 400.534 & 1526.296 & 8.903 \\
\hline
\end{tabular}

Note: *, Significant at 10\%; **, Significant at 5\%; and ***, Significant at I\%

\section{Financial capital}

The household estimated monthly income and the computed per capita income were used to assess the extent to which financial capital influenced coping decisions among flash flood and riverine flood victims (Table 9). In general, financial capital had a very limited influence over adoption decisions by victims as can be seen from the Beta values, irrespective of flood type. Only very weak and even negative contributions were made either by household income or income per capita. Similar to other capital portfolios, a statistically significant contribution was only registered for flash floods $(p \leq 0.1)$ Balgah et al. ${ }^{15,21}$ reported similar results for flash floods in northwest Cameroon. The results however contradict the findings of Berman et al. ${ }^{8}$ Poussin et al. ${ }^{35}$ and Patnaik et al. ${ }^{37}$ who all observed positive relationships between financial capital (household income) and disaster coping decisions.

Table 9 Financial capital variables

\begin{tabular}{lllll}
\hline Variable & Flood type & B & S.E & $\operatorname{Exp(B)}$ \\
\hline $\begin{array}{l}\text { Household } \\
\text { income }\end{array}$ & Flash & $.000^{*}$ & 0 & 1 \\
\multirow{2}{*}{ Per capita income } & Riverine & -0.001 & 0.169 & 0.999 \\
& Flash & $-.001^{*}$ & 0 & 0.999 \\
Riverine & 0.005 & 2.113 & 1.005 \\
Constant & Flash & 80.155 & 34.81 & 6468 \\
& Riverine & 400.534 & 1526.296 & 8.903 \\
\hline
\end{tabular}

Note: *, Significant at 10\%; **, Significant at 5\%; and ***, Significant at I\%

\section{Conclusion}

The escalation of flood hazards and the negative effects they impart especially in developing countries justifies ongoing efforts to understand flood impacts, processes and options that victims have before, during and after such extreme weather events. Investigating drivers for coping decisions and identifying consistencies can pave the way for informed policy prescription which is robust across space and time. As of now, the limited scholarly effort in this direction has been largely championed by isolated individual case studies often applying different methodological approaches, based on the premise that results are context-specific, and that flood policy relevance is higher if it is adapted to each specific geographic space. However, given that resources are limited but floods are increasing in frequency, comprehensive studies of coping strategies stand the chance of providing policy makers in developing countries with trends on which flood management policies that go beyond space and time can be based, in the shortest possible time. A first step will be to cross analyze the many existing individual case studies from developing countries. The reliability of such an approach is arguably torpedoed by the diversity of methodological approaches clearly visible in uncoordinated individual case studies. One way to overcome this shortcoming will be to commence a process of analyzing many empirical case studies at the same time, applying similar methodologies in all the researched case studies.

We applied this logic to model the drivers for flood victims' decisions to adopt predominantly informal coping strategies after 3 independent flash and 3 riverine floods in the Southwest region of Cameroon. In total, 106 flash and riverine flood victims participated in the survey. Collected data were analyzed using the Statistical Package for Social Sciences (SPSS) version 20.0 and Microsoft excel 2010. The capital portfolios of the SLF were appropriated to adapt a structured questionnaire that was applied in the same manner to all the flood victims, irrespective of type and community. Analyses of the empirical data revealed a number of similarities between flash and riverine flood victims. For instance, both flood victims heavily drew on informal networks to cope with the flood effects. In general, social, human, natural and physical capitals were key factors driving victims' coping decisions irrespective of flood type. However, significant relationships were generally observed in flash than riverine floods. This is probably due to the fact that flash floods tend to be more frequent than riverine floods, pushing the former victims to learn through experience, and over time.

The above results lead us to contend that the analysis of multiple case studies applying similar methodologies hold great potentials for generating knowledge that can support policy makers in developing countries to make informed decisions on how to cope with different or similar floods across space and time. This is very crucial for flood hazard management in many developing countries, given the general limitations of state and market institutions for flood management in such countries. Further research is however needed to ground this contention

\section{Acknowledgments}

The authors acknowledge the senior fellowship grant from Volkswagen Foundation, Germany (Grant Nr 89866), which facilitated data collection and analysis, and the write up of this manuscript. 
The participation of enumerators in the data collection process is also acknowledged. The contribution of anonymous referees is also appreciated.

\section{Conflicts of interest}

The authors declare that there is no conflict of interest.

\section{References}

1. World Bank. Managing disaster risk for resilient development. 2014.

2. CRED (Centre for Research on the Epidemiology of Disasters). The Human cost of weather related disasters, 1995-2015. Brussels: The United Nations Office for Disaster Risk Reduction; 2015.

3. Smit B, Pilifosova O. Adaptation to climate change in the context of sustainable development and equity chapter 18. Climate change 2001: Impacts, adaptation, and vulnerability-Contribution of working group II to the third assessment report of the intergovernmental panel on climate change. Cambridge: Cambridge University Press; 2001.

4. IPCC (Intergovernmental Panel on Climate Change). Managing the risks of extreme events and disasters to advance climate change adaptation. A Special Report of Working Groups I and II. New York: Cambridge University Press; 2012.

5. Helgeson F, Dietz S, Hochrainer-Stigler, S. Vulnerability to weather disasters: the choice of coping strategies in rural Uganda. Ecology and Society. 2013:18(2).

6. Tabbabi A. Impact of climate change on vector borne diseases. MOJ Ecology and Environmental Sciences. 2018;3(4):297-298.

7. Ferreira S, Hamilton K, Vincent J. Does development reduce fatalities from natural disasters,? New evidence from floods. Environment and Development Economics. 2013;18(6):649-679.

8. Berman R, Quinn C, Paavola J. Identifying drivers of household coping strategies to multiple climatic hazards in Western Uganda: Implications for adapting to future climatic change. Climate and Development. 2014;1:1-26.

9. Edoun EI, Balgah RA, Mbohwa C. The impact of effective management of natural disasters on Africa's development. Economic Research. 2015;28(1):924-938.

10. Rakib MR, Islam N. Climate change and its impact on agricultural cropping pattern of the Old Brahmaputra floodplain in Bangladesh, Climate Change. 2017;3(12):861-77.

11. Holzmann R. Risk and Vulnerability: the forward looking role of social protection in a globalizing world. Social Protection Discussion Paper No 0109. Washington DC: The World Bank; 2001.

12. Buchenrieder G, Mack C, Balgah RA. Human security and the relocation of internally displaced environmental refugees in Cameroon. Refugee Survey Quarterly. 2017;36(3):20-47.

13. Christiaensen L, Hoffmann V, Sarris A. Gauging the welfare effects of shocks in rural Tanzania. World Bank Policy Research Working Paper 4406, Washington DC: The World Bank; 2007.

14. Thomas T, Christiaensen L, Do QT, et al. Natural disasters and household welfare: Evidence from Vietnam, World Bank Policy Research Working Paper 5491. Washington DC: The World Bank; 2010.

15. Balgah RA, Buchenrieder G, Mbue IM. When nature frowns: A comprehensive impact assessment of the 2012 Babessi floods on people's livelihoods in rural Cameroon. Jamba. 2015;7(1):197.

16. Eriksen SH, Brown K, Kelly PM. The dynamics of vulnerability: Locating coping strategies in Kenya and Tanzania. Geographical Journal. 2005;171(4):287-305.
17. Hisali E, Birungi P, Buyinza F. Adaptation to climate change in Uganda: Evidence from micro level data. Global Environmental Change. 2011;21(4):1245-126.

18. UNISDR. Building back better for next time. Bangkok: UNISDR Asia and Pacific; 2010.

19. Chambers R. Sustainable livelihoods, environment and development: Putting poor rural people first. IDS Discussion Paper, Brighton: Institute of Development Studies; 1987.

20. Scoones I. Sustainable Rural Livelihoods: a framework for analysis. IDS Working Paper; 1998.

21. Balgah RA, Salliana AF, Theobald MN, et al. Determinants for strategies to cope with climate related flood hazards in Cameroon. Climate Change. 2017;3(12):914-923

22. Deressa TT, Hassan RM, Ringler C, et al. Determinants of farmers' choice of adaptation methods to climate change in the Nile Basin of Ethiopia. Global Environmental Change. 2009;19(2):248-255.

23. Holzmann R. Risk and vulnerability: the forward looking role of social protection in a globalizing world. Social Protection Discussion Paper No 0109. Washington DC: The World Bank; 2001.

24. Thornton PK, Boone RB, Galvin KA, et al. Coping strategies in livestock-dependent households in east and southern Africa: A synthesis of four case studies. Human Ecology. 2007;35(4):461-47.

25. Oyekale A, Gedion K. Rural households' vulnerability to climaterelated income shocks and adaption options in central Malawi. Journal of Food Agriculture and Environment. 2012;10:1505-1510.

26. Mavhura E, Manyena S, Collins A, et al. Indigenous knowledge, coping strategies and resilience to floods in Muzarabani, Zimbabwe. International Journal of Disaster Risk Reduction. 2013;5:38-48.

27. WMO. Quality management framework - manual on flood forecasting and warning. Geneva: World Meteorological Organization; 2011.

28. Chantarat S, Cheng K, Minea K. The Effects of natural disasters on households' preferences and behaviors: Evidence from Cambodian rice farmers after the 2011 mega flood. In: Sawada Y, Oum S, editors. Disaster Risks, Social Preferences and Policy Effects: Field Experiments in Selected ASEAN and East Asian Countries. ERIA Research Project Report FY2013, No.34. Jakarta: ERIA; 2015:85-130.

29. Baan P, Kljin W. Flood risk perception and implications for flood risk management in the Netherlands. International Journal of River Basin Management. 2004;2(2):113-122.

30. Botzen W, Aerts J, Van den Berg J. Dependence of flood risk perceptions on socioeconomic and objective risk factors. Water Resources Research. 2009;45:1-15.

31. Miceli R, Sotgiu I, Settanni M. Disaster preparedness and perception of flood risk: A study in an Alpine Valley in Italy. Journal of Environmental Psychology. 2008;28:164-173.

32. Zaalberg R, Midden C, Meijnders A, et al. Prevention, adaptation, and threat denial: flooding experiences in the Netherlands, Risk Analysis. 2009;29(12):1759-1778.

33. Bashiru M, Dumariyi M, Terkpeh G. Drivers for the adoption of risk management practices by farmers in Ghana: Critical Inquiry from the Wa East District. Information Knowledge Management. 2014;4(9):510 .

34. Shitangsu K, Jayant K. Household response to cyclones and induced surge in coastal Bangladesh: coping strategies and explanatory variables. Natural Hazards. 2010;57(2):477-499.

35. Poussin JK, Botzen WJ, Aerts CJ. Factors of influence on flood damage mitigation behaviour by households. Environmental Science Policy. 2014;40:69-77. 
36. Grothmann T, Reusswig F. People at risk of flooding: why some residents take precautionary action while others do not. Natural Hazards. 2006;38(1-2):101-120.

37. Partnaik U, Das P, Bahinipati C. Coping with Climatic Shocks: Empirical Evidence from Rural Coastal Odisha, India. Global Business Review. 2016;17(1):161-175.

38. Ellis F. Household strategies and rural livelihood diversification. Journal of Development Studies. 1998;35(1):1-38.

39. Heitzmann K, Canagarajah RS, Siegel PB. Guidelines for Assessing the Sources of Risk and Vulnerability. Social Protection Discussion Paper Series No. 0128, Social Protection Unit Human Development Network, Washington DC: The World Bank; 2002.

40. Anthony G, Dagmar S, Richard T, et al. Assessing Vulnerability to Global Environmental Change. Making Research Useful to Adaptation to Decision Making and Policy. Earth Scan, Dunston House 14a Cross Street, London ECIN 8XA, UK; 2009.
41. Cardona OD, van Aalst MK, Birkmann J, et al. Determinants of risk: exposure and vulnerability. In: Barros CBV, Stocker TF, Qin D, editors. A special report of working Groups I and II on the Intergovernmental Panel on Climate Change (IPCC). Managing the Risks of Extreme Events and Disasters to Advance Climate Change Adaptation Field, Cambridge: Cambridge University Press; 2012:65-108.

42. Siegrist M, Gutscher H. Flooding risks: A comparison of laypeople's perceptions and expert's assessments in Switzerland. Risk Analysis. 2006;26(4):971-979.

43. Terpstra T. Emotions, trust and perceived risk: affective and cognitive routes to flood preparedness behavior. Risk Analysis. 2011;31(10):16581675 .

44. Mishra S, Suar D. Effects of anxiety, disaster education, and resources on disaster preparedness behavior. Journal of Applied Social Psychology. 2012;42(5):1069-1087. 